\title{
Pengembangan Lembar Kerja Peserta Didik Berkarakter Realistic Mathematic Education Pada Materi Sistem Persamaan Linear Tiga Variabel Kelas X SMA
}

\author{
Necylia Kinanti ${ }^{1}$, Damris ${ }^{2}$, Nizlel Huda ${ }^{3}$ \\ 1, 2, 3 Program Studi Pendidikan Matematika, Universitas Jambi, \\ Jl. Raden Mataher No.16-Jambi, Kota Jambi, Indonesia \\ necyliakinanti@gmail.com
}

\begin{abstract}
This study aims to produce valid and practical student worksheets. This research was developed with the A-DDI-E development model which consists of five stages, namely Analysis, Design, Development, Implementation and Evaluation. The LKPD writing process uses the A-D-DI-E writing model, namely Analyze, Design, Development and Implementation and Evaluation. This research was conducted in September 2020, Academic Year 2020/201. The subjects of this study were 3 mathematics teachers and 8 students of SMAN 2 Jambi City. The results of the development show that the student worksheets with Realistic Mathematic Eduication characteristics on the Three Variable Linear Equation System material are declared valid and worthy of field trials based on the judgment of material experts and design experts. Meanwhile, the three practitioners 'assessment stated that the resulting worksheets were practically used according to the practitioners' suggestions. For the small group trial conducted by 8 students of SMAN 2 Kota Jamb, it was concluded that the comments given by students to the worksheets of students in this small group trial gave a positive response and showed students' interest in using the LKPD during learning.
\end{abstract}

Keyword: Worksheet, Realistic Mathematic Education

\begin{abstract}
Abstrak
Penelitian ini bertujuan untuk mengahasilkan lembar kerja perserta didik yang valid dan praktis. Penelitian ini dikembangkan dengan model pengembangan A-D-DI-E yang terdiri dari lima tahapan yakni Analysis, Design, Development, Implementation dan Evaluation. Adapun proses penulisan LKPD ini menggunakan model penulisan A-D-DI-E yaitu Analyze, Design, Development and Implementation dan Evaluation. Penelitian ini dilakukan pada September 2020 Tahun Akademik 2020/201. Subyek dari penelitian ini adalah 3 orang guru matematika dan 8 orang siswa SMAN 2 Kota Jambi. Hasil pengembangan menunjukkan bahwa lembar kerja peserta didik berkarakter Realistic Mathematic Eduication pada materi Sistem Persamaan Linear Tiga Variabel dinyatakan valid dan layak uji coba lapangan berdasarkan penilaian ahli materi dan ahli desain. Sedangkan penilaian tiga praktisi menyatakan bahwa lembar kerja yang dihasilkan praktis digunakan sesuai dengan saran praktisi. Untuk uji coba kelompok kecil yang dilakukan oleh 8 orang siswa SMAN 2 Kota Jamb disimpulkan bahwa komentar yang diberikan siswa teradap lembar kerja peserta didik dalam uji coba kelompok kecil ini memberikan respons yang positif dan terlihat ketertarikan siswa dalam menggunakan LKPD tersebut saat pembelajaran.
\end{abstract}

Kata Kunci: LKPD, Realistic Mathematic Education

Copyright (c) 2021 Necylia Kinanti, Damris, Nizlel Huda $\triangle$ Corresponding author: Necylia Kinanti, Damris, Nizlel Huda Email Address: necyliakinanti@gmail.com (Jl. Raden Mattaher No.16-Jambi, Kota Jambi, Indonesia) Received 28 November 2020, Accepted 13 Januari 2021, Published 14 Januari 2021

\section{PENDAHULUAN}

Penelitian-penelitian terdahulu mengungkapkan bahwa peserta didik menganggap pelajaran matematika merupakan mata pelajaran yang rumit dan sulit, dengan banyaknya rumus-rumus dan logika yang membingungkan peserta didik (Kamarullah, 2017). Hal tersebut dikarenakan materi pembelajaran yang dipelajari tidak dihubungkan dengan kehidupan sehari-hari atau kehidupan nyata (Gazali, 2016) proses pembelajaran yang dilakukan hanya berupa penyampaian rumus-rumus, dan penyampaian rumus disampaikan oleh guru secara langsung tanpa adanya kesempatan bagi peserta 
didik untuk memikirkan bagaimana pola maupun penyelesaian dari rumus tersebut

Hal ini diperkuat oleh Jenning, Sue dan R. Dunne 1999, (dalam (Suharta \& Putu, 2001)) kebanyakan siswa mengalami kesulitan dalam mengaplikasikan matematika mereka ke dalam situasi kehidupan nyata. Apalagi bila guru dalam pembelajarannya di kelas tidak mengaitkan materi dengan skema yang telah dimiliki siswa dan siswa kurang diberikan kesempatan untuk menemukan kembali dan mengkonstruksi sendiri ide-ide matematika. Blum \&Niss (dalam (Hadi, 2005)) menyatakan bahwa upaya ini dilakukan melalui pengalaman dengan berbagai situasi di luar matematika yang dapat berupa mata pelajaran selain matematika ataupun kehidupan sehari-hari dan lingkungan sekitar.

Menyadari pentingnya peranan matematika maka mengoptimalkan hasil belajar matematika siswa disetiap jenjang pendidikan perlu mendapat perhatian yang sungguh-sungguh agar tujuan dari pendidikan nasional tersebut dapat tercapai. Berdasarkan hasil laporan Programme for International Student Asessment (PISA) skor matematika berada di pringkat 72 dari 78 negara. Hasil tersebut merupakan yang paling rendah diantara mata pelajaran lain. Rendahnya hasil belajar matematika siswa terutama pada pemahaman konsep disebabkan kurangnya alat untuk menyampaikan materi yang menjadi jembatan oleh guru untuk mencapai tujuan pembelajaran tersebut.

Berdasarkan hasil observasi di SMAN 2 Kota Jambi khususnya di kelas X, diperoleh nilai peserta didik sebesar $49 \%$ masih tergolong rendah karena berada di bawah Kriteria Kentuntasan Minimum (KKM) yang ditetapkan sekolah tersebut untuk mata pelajaran matematika kelas $\mathrm{X}$ yakni sebesar 70. Sedangkan sebesar 51\% telah mencapai nilai KKM. Berdasarkan data tersebut dapat disimpulkan bahwa hasil belajar matematika peserta didik masih tergolong rendah.

Dalam suatu pembelajaran matematika, pendidik perlu memberikan motivasi kepada peserta didik agar mereka mau dan mampu menyelesaikan soal-soal, dan bila perlu membimbingnya sampai mereka mampu menyelesaikannya. Bimbingan yang dimaksud dapat diberikan secara lisan maupun secara tertulis, namun bantuan secara tertulis dalam lembar kerja peserta didik jauh lebih efektif, karena dapat dibaca secara berulang-ulang oleh peserta didik. Lembar kerja peserta didik dianggap sebagai salah satu alternatif pembelajaran yang tepat bagi peserta didik.

Oleh karenanya peneliti melakukan analisis kebutuhan berkaitan dengan pembelajaran matematika yang selama ini telah dilakukan. Berdasarkan hasil analisis kebutuhan yang dilakukan peneliti diperoleh bahwa sumber belajar yang digunakan selama ini adalah buku teks dan LKPD, LKPD yang biasa digunakan peserta didik dalam pembelajaran matematika adalah LKPD yang berisi ringkasan materi, contoh dan latihan soal. Penyajiannya langsung kepada materi tanpa memberikan masalah yang berakaitan dengan kehidupan yang dekat dengan peserta didik. Selain itu soal-soal yang digunakan juga kebanyakan tidak berasarkan permasalahan nyata.

Selain itu, dari tanggapan peserta didik kelas X disimpulkan bahwa bahan ajar yang digunakan selama ini juga masih belum bisa menarik minat belajar peserta didik, peserta didik lebih tertarik pada 
LKPD yang berwarna dan bergambar serta berisi soal-soal yang dekat dengan kehidupan mereka sehari-hari (realistik).

Berdasarkan uraian di atas, pembelajaran matematika harusnya ditekankan pada keterkaitan antara konsep-konsep matematika dengan pengalaman peserta didik sehari-hari. Hal ini sejalan dengan konsep Realistic Mathematic Education dengan menciptakan pembelajaran yang bermakna dan realistik sehingga dapat menarik minat belajar peserta didik sehingga peserta didik mampu menyelsaikan masalah matematika dan meningkatkan hasil belajar matematika.

Pendekatan RME dipilih karena kegiatan pokoknya adalah menyelesaikan soal matematika berbentuk cerita melalui rangkaian kegiatan bersama atau kelompok, sehingga peserta didik dapat terlibat langsung secara aktif dalam proses pembelajaran (Kusumawati, 2017). Pada kegiatan diskusi kelompok, peserta didik dapat melakukan aktivitas seperti mengkonstruksi berbagai pengetahuan yang diperlukan, mengkomunikasikan pendapat, menimbang atau menerima pendapat orang lain serta dapat mengambil kesimpulan atau saran. Selain itu, RME menggabungkan pandangan tentang apa itu matematika, bagaimana peserta didik belajar matematika dan bagaimana matematika harus diajarkan. Peserta didik tidak boleh dilihat sebagai objek belajar, melainkan sebagai subyek belajar (Atika \& MZ, 2016). RME juga mengaplikasikan fenomena dengan aplikasi yang nyata pada peserta didik dalam memulai proses pembelajaran. Dengan soal-soal kontekstual, peserta didik diarahkan dan dibimbing oleh guru secara konstruktif sampai peserta didik menjadi mengerti konsep matematika yang sedang dipelajarinya (Erita, 2016) Sehingga dari penguasaan konsep tersebut, peserta didik diharapkan memperoleh hasil belajar yang lebih baik. Dalam proses pembelajaran dengan RME, peserta didik lebih dituntut menggambarkan materi secara nyata, sehingga materi dapat ditemukan dan dikembangakan sendiri oleh peserta didik.

Realistic Mathematic Education (RME)

Realistic Mathematics Education (RME) atau Pendidikan Matematika Realistik (PMR) berasal dari negeri Belanda telah berkembang sejak tahun 1970-an. Hans Freudenthal (Wijaya, 2012) mencetuskan RME berlandaskan pada filosofi matematika sebagai aktivitas manusia (mathematics as human activity). Menurut (Zulkardi, 1999) "two of his important points of views are mathematics must be connected to reality and mathematics as human activity. First, mathematics must be close to children and be relevant to everyday life situations. Second, the idea of mathematics as a human activity is stressed".

Realistic Mathematics Education (RME) atau Pembelajaran Matematika Realistik (PMR) adalah sebuah teori belajar mengajar dalam pendidikan matematika. Teori ini pertama kali diperkenalkan dan dikembangkan di Belanda pada tahun 1970 oleh institute Freudenthal. RME telah dikembangkan dan diujicobakan selama 33 tahun di Belanda dan terbukti berhasil merangsang penalaran dan kegiatan berpikir siswa (Hobri, 2009)Teori ini mengacu kepada pendapat Freudental 
yang mengatakan bahwa matematika harus dikaitkan dengan realita dan matematika merupakan aktivitas manusia. Ini berarti matematika harus dekat dengan anak dan relevan dengan kehidupan nyata sehari-hari (Hobri, 2009).

Aktivitas belajar yang berbasis pada pembelajaran matematika realistik adalah siswa secara aktif mengkonstruksi sendiri pengetahuan matematika. Hal terpenting adalah siswa dapat mengetahui kapan dan dalam konstruk apa mereka menerapkan konsep-konsep matematika itu dalam menyelesaikan suatu persoalan. Sedangkan guru bukan lagi penyampai informasi yang sudah jadi, tetapi sebagai pendamping bagi siswa untuk aktif mengkonstruksi (Ningsih, 2014).

Prinsip-prinsip pokok pembelajaran matematika secara PMR yang dikemukakan oleh (Marpaung, 2001)yaitu :

1. Prinsip Aktivitas. Prinsip ini menyatakan bahwa matematika adalah aktivitas manusia. Matematika paling baik dipelajari dengan melakukannya sendiri.

2. Prinsip Realitas. Prinsip ini menyatakan bahwa pembelajaran matematika dimulai dari masalahmasalah dunia nyata yang dekat dengan pengalaman siswa (masalah yang realistis bagi siswa). (Catatan: realistis bagi siswa diartikan tidak selalu berkaitan dengan dunia nyata, bisa juga dari dunia lain tetapi dapat dibayangkan oleh siswa). Jika matematika diajarkan lepas dari pengalaman siswa maka matematika itu mudah dilupakan.

3. Prinsip Penjenjangan. Prinsip ini menyatakan bahwa pemahaman siswa terhadap matematika melalui berbagai jenjang yaitu dari menemukan (to invent) penyelesaian kontekstual secara informal ke skematisasi. Kemudian perolehan insight dan penyelesaian secara formal.

4. Prinsip Jalinan. Prinsip ini menyatakan bahwa materi matematika di sekolah tidak di pecah-pecah menjadi aspek-aspek (learning strands) yang diajarkan terpisah-pisah.

5. Prinsip Interaksi. Prinsip ini menyatakan bahwa belajar matematika dapat dipandang sebagai aktivitas sosial selain sebagai aktivitas individu. (Prinsip ini sesuai dengan pandangan filsafat konstruktivisme, yaitu bahwa di satu pihak pengetahuan itu adalah konstruksi sosial (Vygotsky) dan di lain pihak sebagai konstruksi individu (Piaget).

6. Prinsip Bimbingan. Prinsip ini menyatakan bahwa dalam menemukan kembali (reinvent) matematika, siswa perlu mendapat bimbingan

Secara umum, Pendekatan Pembelajaran Matematika Realistik (PMR) atau RME memiliki lima karakteristik yaitu: 1)the use of contexts (penggunaan konteks), 2) the use of models (penggunaan model), 3) the use of students own production and constructuins (penggunaan kontribusi dari peserta didik sendiri), 4) the interactive character of teaching process (interaktif dalam proses pengajaran), dan 5) the interviewments of various learning strands (terintegrasi dengan berbagai topic pembelajaran lainnya) menurut De Lange dalam (Silvianti \& Bharata, 2016). Sedangkan(Treffers, 1991) menyebutkan karakteristik RME yang membedakan dengan pendekatan pembelajaran yang lain adalah (1) penggunaan masalah konstektual (the use of context), (2) penggunaan 
model (the use of models), (3) penggunaan konstribusi siswa (student contribution), (4) interaktivitas (interactivity), dan (5) integrasi dengan topik pembelajaran yang lainnya (intertwining).

Menurut (Hidayati, 2013) secara konkrit, penerapan Realistic Mathematics Education atau Pendidikan Matematika Realistik dalam pembelajaran dapat digambarkan dengan langkah-langkah operasional sebagai berikut: (1) Pemberian masalah oleh guru; (2) Penyelesaian masalah oleh siswa dengan cara mereka sendiri; (3)Siswa yang memiliki penyelesaian masalah yang berbeda-beda mempresentasikan hasil pelerjaannya; (4)Siswa lain memberikan tanggapan terhadap pekerjaan yang telah dipresentasikan; (5) Dari beberapa penyelesaian dan hasil diskusi, akhirnya melalui proses negosiasi siswa memilih penyelesaian yang paling baik; (6) Siswa mengakhiri kegiatan penyelesaian masalah dengan refleksi. Berdasarkan pendapat di atas dapat disimpulkan bahwa langkah-langkah pembelajaran

\section{Lembar Kerja Peserta Didik (LKPD)}

Pada abad ke-21, siswa dituntut untuk mengembangkan kompetensi generik (kreativitas, komunikasi, pendidikan karakter, literasi dan pemikiran kritis) agar tujun pembelajarn tercapai (Festiyed, 2015). Untuk mencapai tujuan tersebut guru harus pandai memilih bahan ajar yang tepat digunakan pada saat pembelajaran. Pernyataan ini didukung (Yezita, 2012) yang menyatakan bahwa "bahan ajar adalah segala bentuk bahan yang digunakan untuk membantu guru/instruktur dalam melaksanakan kegiatan pembelajaran di kelas yang disusun secara sistematis baik tertulis maupun tidak tertulis".

Bahan ajar adalah segala bentuk bahan yang digunakan untuk membantu guru/instruktur dalam melaksanakan kegiatan belajar mengajar di kelas (Nugraha \& Binadja, 2013). Sedangkan (Sudibyo \& Dr, 2007) mengemukakan bahwa, "bahan ajar merupakan seperangkat materi/substansi pembelajaran (teaching material) yang disusun secara sistematis, menampilkan sosok utuh dari kompetensi yang akan dikuasai siswa dalam kegiatan pembelajaran". Konsep "bahan ajar" dalam kajian ilmiah memiliki banyak pengertian. Menurut National Center for Vocational Education research ltd., (Prastowo, 2011)"bahan ajar adalah segala bentuk bahan yang digunakan untuk membantu guru atau instruktur dalam melaksanakan proses pembelajaran di kelas".

Menurut (Lestari, 2013) sesuai dengan pedoman pedoman penelitian modul yanng dikeluarkan oleh Direktorat Guruan Menengah Kejuruan Direktorat Jenderal Pendidikan Dasar dan Menengah Departemen Pendidikan Nasional Tahun 2003, bahan ajar memiliki beberapa karakteristik, yaitu sel instructional, self contained, stand alone, adaptive, dan user friendly. Berdasarkan bentuknya (Prastowo, 2011) membagi bahan ajar menjadi empat macam yaitu: Bahan ajar cetak (print), bahan ajar dengar atau program, bahan ajar pandang dengar, dan bahan ajar interaktif. 
Menurut (Trianto, 2009)"Lembar Kerja Siswa adalah panduan siswa yang digunakan untuk melakukan kegiatan penyelidikan atau pemecahan masalah". Pada umumnya LKS berisi petunjuk kerja, percobaan yang bisa dilakukan dirumah, materi untuk diskusi, teka-teki silang, tugas portofolio, dan soal-sola latihan maupun segala bentuk petunjuk yang mampu mengajak siswa beraktivitas dalam proses pembelajaran. LKS dapat berupa panduan untuk latihan pengembangan aspek kognitif maupun panduan untuk pengembangan semua aspek pembelajaran dalam bentuk panduan eksperimen atau demonstrasi.

(Ekawati, 2017) mengkategorikan lembar kerja peserta didik menjadi 2 macam yaitu: Lembar kerja peserta didik tak berstruktur dan Lembar kerja peserta didik berstruktur. Lembar kerja peserta didik tak berstruktur adalah lembaran yang berisi sarana untuk materi pelajaran, sebagai alat bantu kegiatan peserta didik yang dipakaiuntuk menyampaikan pelajaran. Sedangkan lembar kerja peserta didik berstruktur memuat informasi, contoh dan tugastugas. Lembar kerja peserta didik ini dirancang untuk membimbing peserta didik dalam satu program kerja atau mata pelajaran, dengan sedikit atau sama sekali tanpa bantuan pembimbing untuk mencapai sasaran pembelajaran. Pada lembar kerja peserta didik telah disusun petunjuk dan pengarahannya. (Lismawati, 2010) menjelaskan bahwa LKPD memiliki keunggulan dan kelemahan yakni keunggulan dilihat dari aspek penggunaan merupakan media yang paling mudah, dapat dipelajari di mana saja dan kapan saja tanpa harus menggunakan alat khusus. Sedangkan kelemahannya ialah LKPD tidak mampunya mempresentasikan gerakan, pemaparan materi bersifat linear, tidak mampu mempresentasikan kejadian secara berurutan, sulit memberikan bimbingan kepada pembacanya yang mengalami kesulitan memahami bagian bagian tertentu, sulit memberikan umpan balik untuk pertanyaan yang diajukan yang memiliki banyak kemungkinan jawaban atau pertanyaan yang membutuhkan jawaban yang kompleks dan mendalam,

\section{METODE}

Jenis penelitian ini adalah penelitian pengembangan. Model yang digunakan dalam penelitian ini adalah model penelitian ADDIE yang terdiri dari lima tahapan yakni Analysis, Design, Development, Implementation dan Evaluation

Jenis data dalam penelitian ini adalah data kualitatif yang diperoleh dari angket validasi ahli materi, ahli desain pembelajaran dan ahli praktikalitas produk yang dalam hal ini dilakukan oleh 3 orang praktisi yaitu guru matematika. Hasil yang diperoleh berupa saran perbaikan terhadap LKPD berbasis Realistic Mathematic Education pada materi SPLTV kelas X dan persepsi guru serta peserta didik. Sedangkan instrumen yang digunakan dalam penelitian ini adalah angket yang diberikan 
kepada validator ahli dan praktisi serta angket persepsi siswa. Validator ahli mencakup ahli desain pembelajaran, ahli materi dan RME, serta ahli desain LKPD. Pada validasi praktisi mencakup tiga orang guru matematika untuk melihat praktikalitas produk LKPD yang dikembangkan. Sedangkan angket persepsi siswa digunakan untuk melihat tanggapan peserta didik dalam uji coba kelompok kecil sebanyak 8 orang siswa SMAN 2 Kota Jambi dari segi daya tarik siswa dalam menggunakan LKPD.

Data yang diperoleh dari uji coba validasi kemudian dianalisis untuk menjawab apakah LKPD berkarakter Realistic Mathematic Education yang dikembangkan sudah dikatakan valid atau belum. Sedangkan data hasil ujicoba kepada praktisi digunakan untuk menjawab kriteria kepraktisan dan keefektifan dari bahan ajar yang dikembangkan. Pada pengolahan data kualitatif, peneliti mendiskusikan dengan tim penelitian berupa saran perbaikan dari tim ahli, praktisi dan pengguna yang berkaitan dengan LKPD yang dikembangkan, menentukan langkah merevisi produk berdasarkan saran naratif dari tim ahli, praktisi dan pengguna untuk

\section{HASIL DAN DISKUSI}

Dalam pengembangan LKPD ini menggunakan model penulisan A-D-DI-E yaitu Analyze, Design, Development and Implementation dan Evaluation.

\section{Analyze}

Adapun yang dilakukan penulis dalam tahap ini adalah analisis kurikulum, analisis materi dan analisis karakteristik guru dan peserta didik. Analisis Kurikulum diperoleh melalui wawancara dengan guru matematika di SMAN 2 Kota Jambi, kurikulum yang digunakan adalah kurikulum 2013 dan materi SPLTV diajarkan pada jenjang SMA Kelas X Semester Ganjil. Adapun kompetensi inti dan kompetensi dasar dapat dilihat pada tabel 1 berikut:

Tabel 1. Kompetensi Inti dan Kompetensi Dasar Materi SPLTV

\begin{tabular}{|c|c|}
\hline Kompetensi Inti & Kompetensi Dasar \\
\hline 1 & 2 \\
\hline $\begin{array}{l}\text { 1. Menghayati dan mengamalkan ajaran } \\
\text { agama yang dianutnya. } \\
\text { 2. Menghayati dan mengamalkan } \\
\text { perilaku jujur, disiplin, santun, peduli (gotong } \\
\text { royong, kerjasama, toleran, damai), bertanggung } \\
\text { jawab, responsif, dan pro-aktif dalam berinteraksi } \\
\text { secara efektif sesuai dengan perkembangan anak } \\
\text { di lingkungan, keluarga, sekolah, masyarakat dan } \\
\text { lingkungan alam sekitar, bangsa, negara, kawasan } \\
\text { regional, dan kawasan internasional. } \\
\text { 3. Memahami, menerapkan, dan } \\
\text { menganalisis pengetahuan faktual, konseptual, } \\
\text { prosedural, dan metakognitif berdasarkan rasa } \\
\text { ingin tahunya tentang ilmu pengetahuan, } \\
\text { teknologi, seni, budaya, dan humaniora dengan } \\
\text { wawasan kemanusiaan, } \\
\text { kebangsaan, kenegaraan, dan peradaban }\end{array}$ & $\begin{array}{l}\text { 2.1 Menunjukkan sikap jujur, tertib } \\
\text { dan mengikuti aturan, konsisten, disiplin } \\
\text { waktu, ulet, cermat dan teliti, maju } \\
\text { berkelanjutan, bertanggung jawab, berpikir } \\
\text { logis, kritis, kreatif, dan analitis, serta } \\
\text { memiliki rasa senang, motivasi internal, ingin } \\
\text { tahu dan ketertarikan pada ilmu pengetahuan } \\
\text { dan teknologi, sikap terbuka, percaya diri, } \\
\text { kemampuan bekerjasama, toleransi, santun, } \\
\text { objektif, dan menghargai. } \\
\text { 3.3Menyusun sistem persamaan linear } \\
\text { tiga variabel dari masalah kontekstual. } \\
\text { 4.3. Menyelesaikan masalah } \\
\text { kontekstual yang berkaitan dengan sistem } \\
\text { persamaan linear tiga variabel. }\end{array}$ \\
\hline
\end{tabular}


terkait penyebab fenomena dan kejadian, serta menerapkan pengetahuan prosedural pada bidang kajian yang spesifik sesuai dengan bakat dan minatnya untuk memecahkan masalah.

4. Mengolah, menalar, dan menyaji dalam ranah konkret dan ranah abstrak terkait dengan penulisan dari yang dipelajarinya di sekolah secara mandiri, bertindak secara efektif dan kreatif, serta mampu menggunakan metode sesuai kaidah keilmuan.

Berdasarkan hasil analisis silabus diperoleh bahwa alokasi waktu yang digunakan dalam mempelajari materi SPLTV adalah 10 jam pelajaran dengan 2-3 jam setiap kali pertemuan dalam seminggu. Satu kali pertemuan membutuhkan waktu 1 x 45 menit.Sehingga disimpulkan bahwa untuk mempelajari materi SPLTV dibutuhkan waktu 5 kali pertemuan dalam kegiatan pembelajaran di kelas. Materi yang digunakan pada penulisan LKPD berkarakter Realistic Mathematic Education adalah Sistem Persamaan Linear Tiga Variabel (SPLTV). SPLTV dipilih karena masih banyak siswa yang melakukan kesalahan selama menyelesaikan soal-soal berbentuk cerita seperti SPLTV. Adapun literatur yang menjadi pedoman dalam analisis materi adalah "Matematika Buku Guru" dan "Matematika Buku Siswa" yang bersumber dari Kementrian Pendidikan dan Kebudayaan (Kemendikbud).

Analisi karakteristik peserta didik diperoleh melalui wawancara kepada guru bidang studi matematika serta melakukan wawancara kepada peserta didik dengan kemampuan tinggi, sedang dan rendah tentang pengalaman belajar matematika di kelas. Berdasarkan hasil wawancara dengan guru matematika diketahui bahwa karakteristik siswa SMAN 2 Kota Jambi kelas X masih belum mandiri dalam mengerjakan soal dan kesulitan dalam menyelesaikan soal-soal berbentuk cerita., masih perlu didampingi oleh guru atau teman sejawatnya. Selain itu masih banyak peserta didik yang kurang fokus dan tidak serius dalam pembelajaran, serta lebih suka berkelompok.

\section{Design}

Dalam tahap ini penulis melakukan beberapa hal seperti menentukan tim penulis, merancang LKPD, penyusunan kerangka dasar LKPD (Story Board) serta penyusunan instrumen penilaian. Berikut storyboard rancangan awal lembar kerja peserta didik berkarakter Realistic Mathematic Education pada materi SPLTV kelas X SMA.

Tabel 2. Storyboard

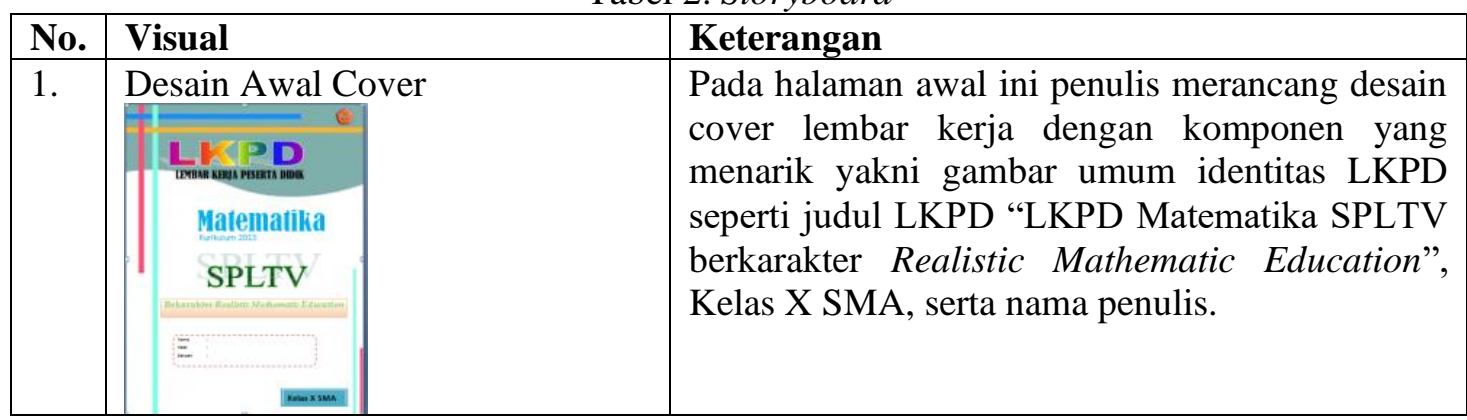




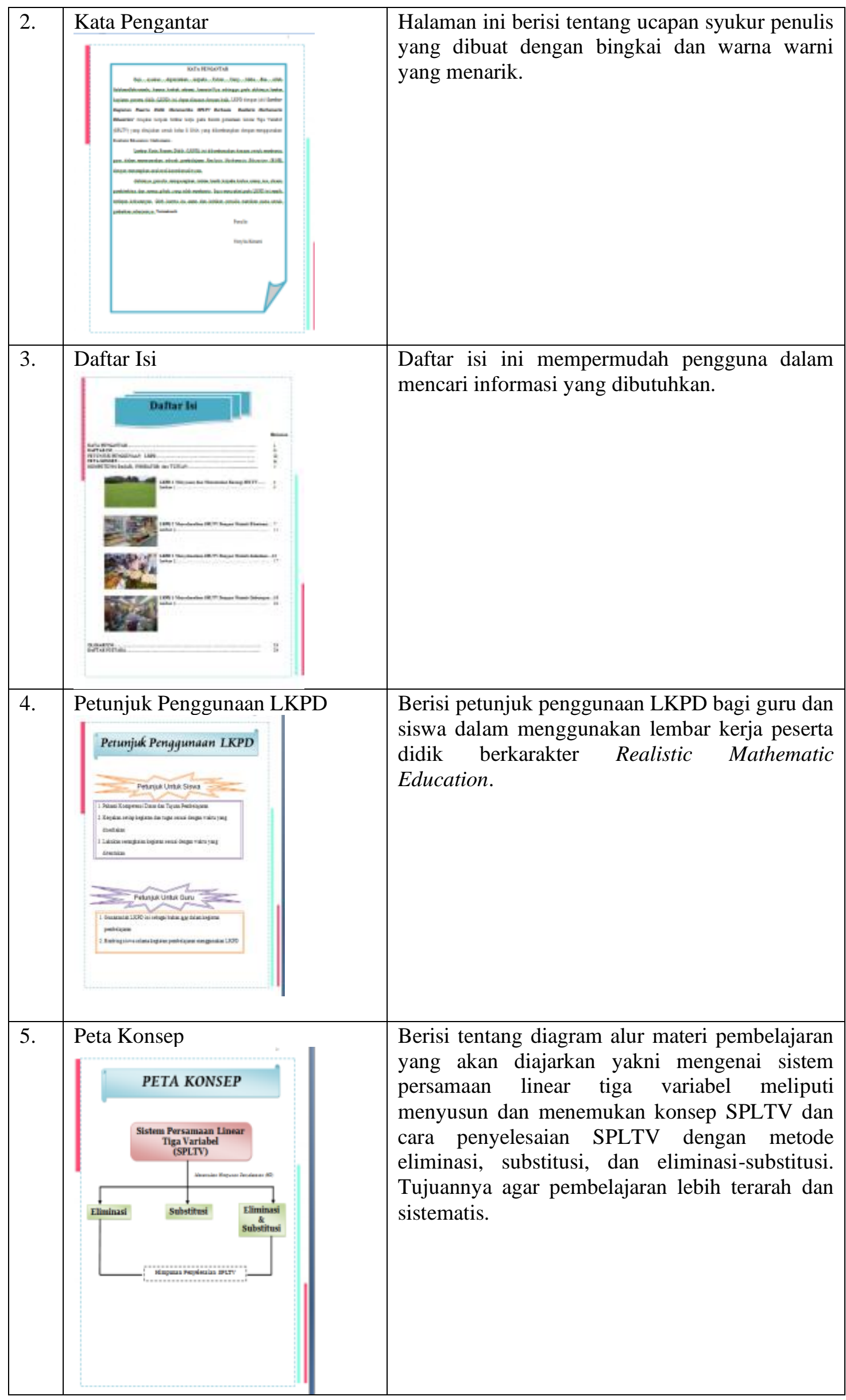




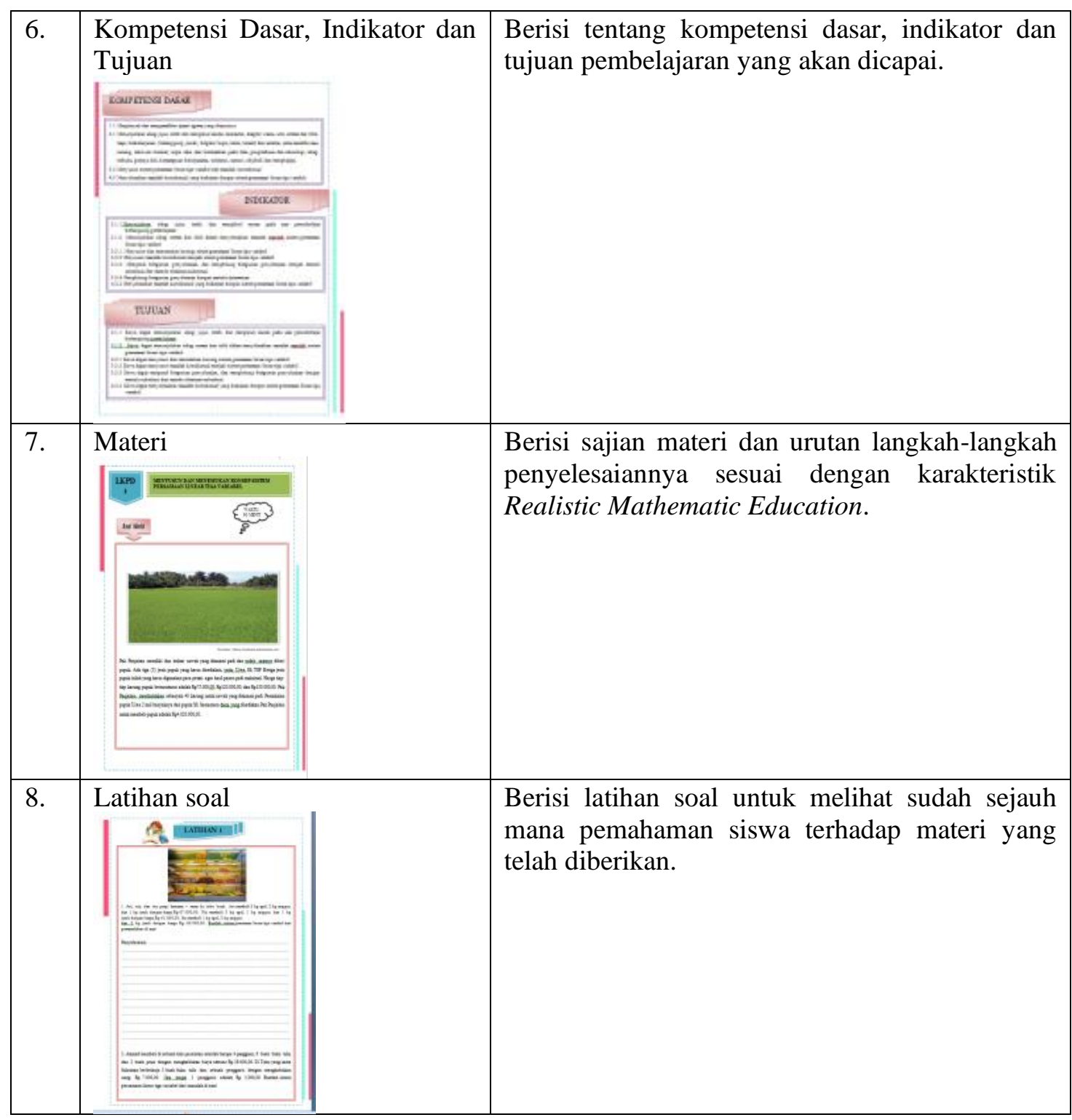

\section{Development and Implementation}

Pada tahap ini, peneliti mengembangkan produk yang tela dirancang sebelumnya kemudian melakukan validasi kepada tim ahli untuk melihat layak atau tidaknya secara konseptual LKPD berkarakter Realistic Mathematic Education pada materi SPLTV Kelas X SMA. Dalam hal ini penilaian dilakukan oleh ahli materi dan ahli desain pembelajaran serta ahli desain media/produk. Setelah melalui validasi oleh tim ahli, maka dilakukan penilaian produk oleh praktisi dan siswa untuk melihat layak atau tidaknya secara prosedural LKPD berkarakter Realistic Mathematic Education pada materi SPLTV Kelas X SMA. Adapun langkah-langkah pengolahan data kualitatif penelitian desain dan pengembangan menurut (Rusdi, 2018)yaitu:

\section{Ahli Materi dan Desain Pembelajaran}

Mengolah dan Mengorganisir Data, Membaca dan Mencatat Substansi Koreksi/Revisi Penilaian lembar kerja peserta didik dilakukan oleh satu orang dosen pascasarjana UNJA dengan menganalisis produk berdasarkan aspek-aspek yang ditentukan dalam angket validasi materi dan 
angket desain pembelajaran. Validasi ini bertujuan untuk melihat kevalidan isi materi dan desain pembelajaran yang digunakan dalam lembar kerja peserta didik berkarakter Realistic Mathematic Educaion pada mada materi SPLTV

\section{Mendeskripsikan Substansi Koreksi/Revisi}

LKPD yang dikembangkan harusnya memperhatikan fokus peserta didik yakni sosiokultur peserta didik bukan dari sumber buku yang belum tentu sesuai. Ahli juga mengatakan bahwa konteksnya belum sesuai jika diberikan pada peserta didik yang tinggal di kota, dan perlu diperkaya dengan masalah kekinian.

\section{Mendiskusikan Tindakan Revisi}

Peneliti melakukan perbaikan secara keseluruhan tentang konsep yang digunakan, mengaitkan materi dengan mengintegrasikan kehidupan sosial budaya masyarakat Jambi kedalam materi ajar. Adapun budaya Jambi yang digunakan seperti Batik Jambi, makanan khas Jambi, serta mall yang ada di Jambi seperti Jamtos, serta menambahkan masalah kekinian seperti yang berkaitan dengan Covid-19 ke dalam materi ajar.

Memformulasikan Tindakan Kongkret

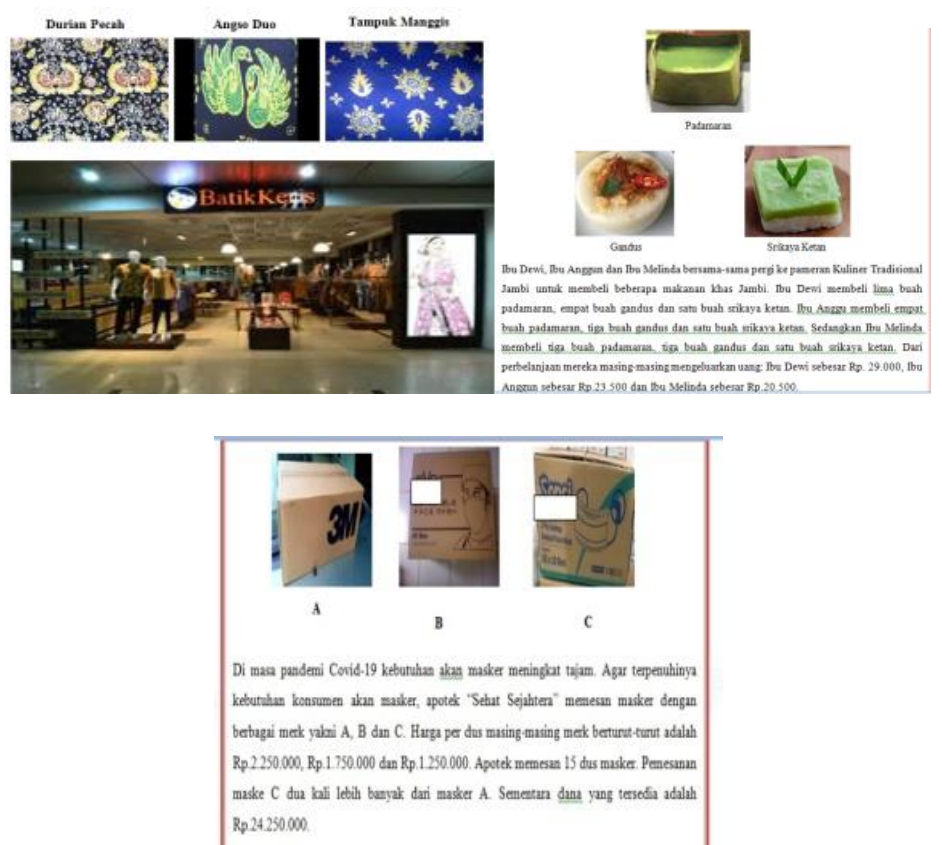

Gambar 1. Hasil Revisi Materi dan Desain Pembelajaran

\section{Ahli Media}

Mengolah dan Mengorganisir Data, Membaca dan Mencatat Substansi Koreksi/Revisi

Penilaian lembar kerja peserta didik dilakukan oleh satu orang dosen pascasarjana UNJA dengan menganalisis produk berdasarkan aspek-aspek yang ditentukan dalam angket validasi materi dan angket desain pembelajaran. Validasi ini bertujuan untuk melihat kevalidan isi materi dan desain pembelajaran yang digunakan dalam lembar kerja peserta didik berkarakter Realistic Mathematic Educaion pada mada materi SPLTV 


\section{Mendeskripsikan Substansi Koreksi/Revisi}

Desain cover lembar kerja sebaiknya ada background/simbol matematika, gambar-gambar sebaiknya ditambah, kemudian ukuran dan letaknya disesuaikan dengan prinsip estetika, serta menambahkan variasi jenis huruf yang menarik, terutama pada hak-hal yang krusial

\section{Mendiskusikan Tindakan Revisi}

Peneliti memasukan gambar dari materi yang akan diajarkan dalam lembar kerja siswa tersebut dikarenakan materi yang digunakan dalam pengembangan lembar kerja peserta didik ini adalah sistem persamaan linear tiga variabel (SPLTV) sehingga tidak ada simbol spesifik, menambahkan gambargambar dari materi yang akan diajarkan sebagai gambaran dari isi lembar kerja itu sendiri, menggunakan jenis huruf yang berbeda pada bagian-bagian yang dianggap krusial.

\section{Memformulasikan Tindakan Kongkret}

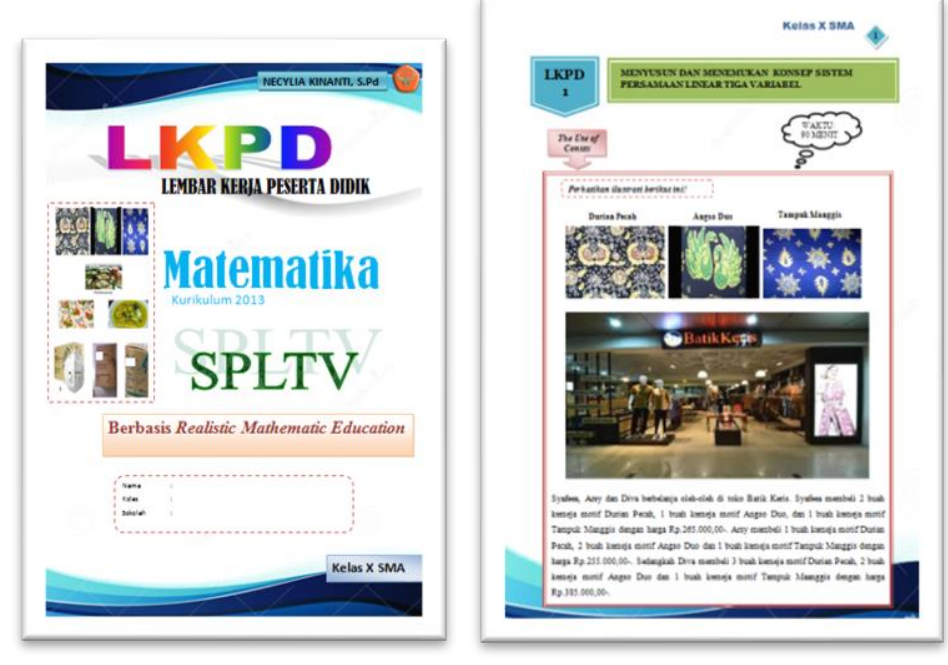

Gambar 2. Hasil Revisi Desain LKPD

\section{Praktisi 1}

Mengolah dan Mengorganisir Data, Membaca dan Mencatat Substansi Koreksi/Revisi

Angket yang diberikan kepada praktisi bertujuan untuk menilai kriteria berdasarkan pesan yang hendak disampaikan, keterkaitan materi dengan Realistic Mathematic Education ${ }_{5}$ Prosedur dan Pemanfaatan lembar kerja peserta didik bagi guru. Penilian dilakukan sesuai dengan aspek-aspek penilaian yang telah ditentukan dalam angket validasi praktisi.

\section{Mendeskripsikan Substansi Koreksi/Revisi}

Praktisi menyarankan agar menggunakan bahasa yang sderhana terutama pada langkahlangkah RME, langkah kerja yang urut dan mudah dipahami serta instruksi yang rinci dan jelas, serta menggunakan kombinasi gambar yang sesuai dengan ilustrasi.

\section{Mendiskusikan Tindakan Revisi}

Penulis menyederhanakan tatanan bahasa pada langkah-langkah kerja, menyesuaikan gambar yang digunakan dengan ilustrasi cerita dan diperjelas satuannya dalam permisalan, 
Memformulasikan Tindakan Kongkret

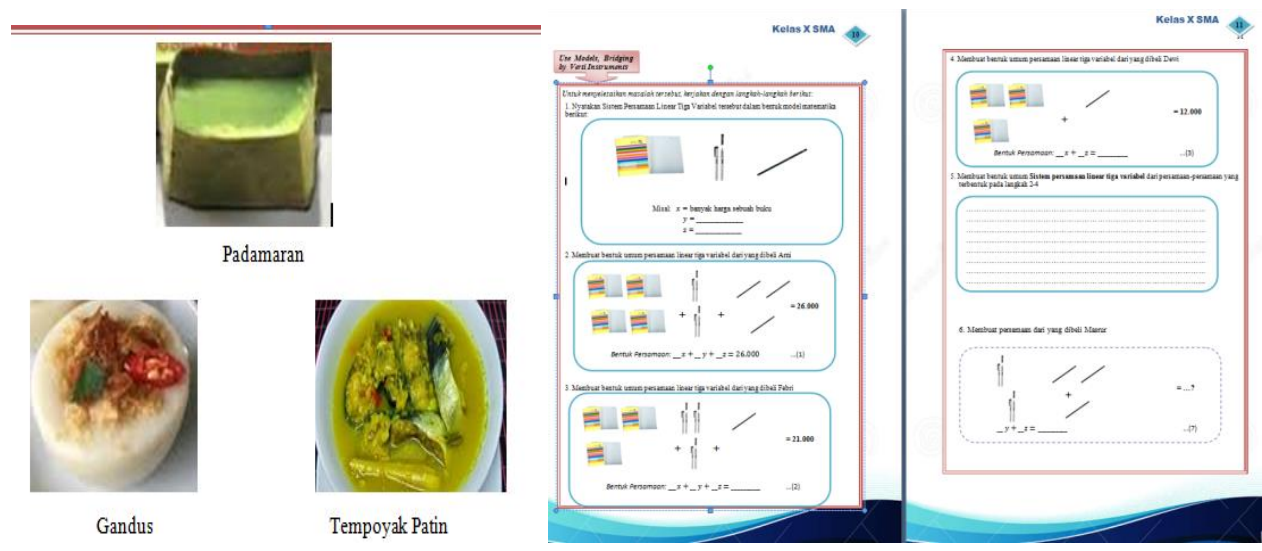

Gambar 3. Hasil Revisi Praktisi 1

\section{Praktisi 2}

\section{Mengolah dan Mengorganisir Data, Membaca dan Mencatat Substansi Koreksi/Revisi}

Angket yang diberikan kepada praktisi bertujuan untuk menilai kriteria berdasarkan pesan yang hendak disampaikan, keterkaitan materi dengan Realistic Mathematic Education,Prosedur dan Pemanfaatan lembar kerja peserta didik bagi guru. Penilian dilakukan sesuai dengan aspek-aspek penilaian yang telah ditentukan dalam angket validasi praktisi.

Mendeskripsikan Substansi Koreksi/Revisi

Penggunaan bahasa, penyampain pesan dan langkah kerja yang ringkas, mudah dimengerti dan dipahami, LKPD harus Memfasilitasi siswa berinteraksi, Gunakan ilustrasi dan gambar yang menarik.

\section{Mendiskusikan Tindakan Revisi}

Memperbaiki bahasa, penyampain pesan dan langkah kerja yang ringkas, mudah dimengerti dan dipahami, Memfasilitasi siswa berinteraksi, memperbaiki gambar-gambar yang digunakan dan disesuaikan satuan(kuantitas) gambar dengan ilustrasi soal.

\section{Memformulasikan Tindakan Kongkret}
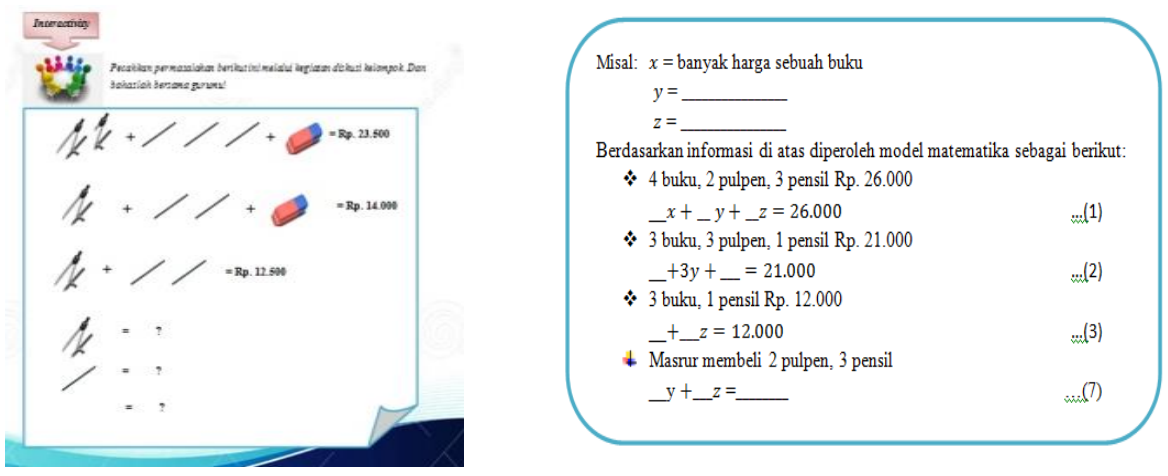

Gambar 4. Hasil Revisi Berdasarkan Saran Praktisi 2

Praktisi 3

Mengolah dan Mengorganisir Data, Membaca dan Mencatat Substansi Koreksi/Revisi 
Angket yang diberikan kepada praktisi bertujuan untuk menilai kriteria berdasarkan pesan yang hendak disampaikan, keterkaitan materi dengan Realistic Mathematic Education ${ }_{5}$ Prosedur dan Pemanfaatan lembar kerja peserta didik bagi guru. Penilian dilakukan sesuai dengan aspek-aspek penilaian yang telah ditentukan dalam angket validasi praktisi.

\section{Mendeskripsikan Substansi Koreksi/Revisi}

Berikan tantangan belajar bagi siswa, Penyajian lembar kerja dan langkah kerja yang urut dan ringkas. Mendiskusikan Tindakan Revisi

Memberikan soal-soal dengan tingkat kesulitan yang bervariasi seperti soal-soal HOTS, Memperbaikan tampilan lembar kerja dan langkah kerjamenjadi lebih urut dan ringkas.

\section{Memformulasikan Tindakan Kongkret}
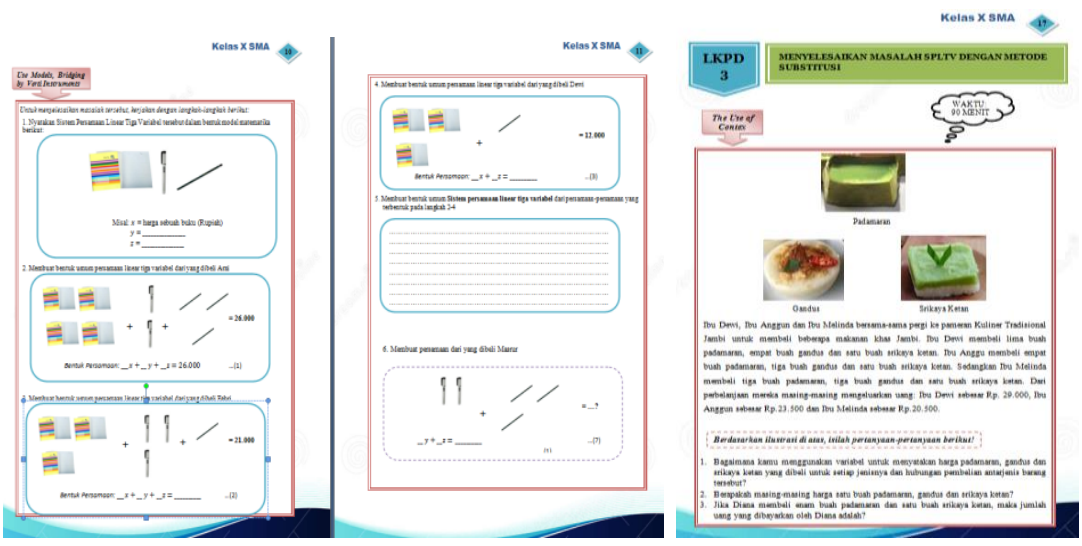

Gambar 5. Hasil Revisi Praktisi 3

Uji coba selanjutnya adalah uji coba kelompok kecil. Hal ini dilakukan oleh siswa siswi kelas XI SMAN 2 Kota Jambi dengan siswa uji bejumlah 8 orang siswa yang berkemampuan rendah, sedang dan tinggi. Pemilihan siswa untuk uji coba ini dibantu oleh guru mata pelajaran Matematika yang mengajar di kelas tersebut karena ia lebih tahu kemampuan dan karakteristik peserta didiknya. Berdasarkan rekapitulasi tanggapan disimpulkan bahwa komentar yang diberikan siswa teradap lembar kerja peserta didik dalam uji coba kelompok kecil ini memberikan respons yang positif dan terlihat ketertarikan siswa dalam menggunakan LKPD tersebut saat pembelajaran. Secara umum tanggapan yang diberikan para siswa terhadap lembar kerja ini adalah baik untuk dijadikan sumber belajar, bahasa penyampaian yang digunakan mudah dipahami, mampu menarik perhatian siswa untuk belajar sehingga nantinya diharapkan mampu meningkatkan hasil belajar siswa.

\section{KESIMPULAN}

Berdasarkan hasil dan pembahasan, maka diperoleh kesimpulan sebagai berikut:

1. Proses tahapan pengembangan lembar kerja peserta didik berkarakter Realistic Mathematic Education pada materi SPLTV kelas X SMA melalui tahap A-D-DI-E yaitu Analyze, Design, Development and Implementation dan Evaluation. 
2. Secara konseptual LKPD Berkarakter Realistic Mathematic Education (RME) pada Materi SPLTV

Kelas X SMA dinyatakan layak oleh ahli materi dan ahli media.

3. Secara prosedural LKPD Berkarakter Realistic Mathematic Education (RME) pada Materi SPLTV

Kelas X SMA dinyatakan praktis oleh ahli praktisi dan juga berdasarkan persepsi siswa.

\section{UCAPAN TERIMA KASIH}

Peneliti mengucapkan syukur kepada Allah SWT atas kelancaran dalam menyelesaikan artikel ini. Kemudian juga berterimakasih kepada kedua orang tua, Bapak Agus Maksudi dan Ibu Umi Fatmawati serta suami Nofriadi, S.Pd yang telah memberikan dukungannya. Terimakasih kepada dosen pembimbing, Bapak Prof. Drs. Damris M., M.Sc., Ph.D dan Ibu Nizlel Huda, M.Kes yang telah memberikan bimbingan serta arahan dalam menyelesaikan artikel ini. Serta terimakasih kepada saudara dan para sahabat yang selalu memberikan dukungannya.

\section{REFERENSI}

Atika, N., \& MZ, Z. A. (2016). Pengembangan LKS Berbasis Pendekatan RME untuk Menumbuhkembangkan kemampuan berpikir kritis matematis siswa. Suska Journal of Mathematics Education, 2(2), 103-110.

Ekawati, W. (2017). Pengembangan LKPD Berbasis Inkuiri Terbimbing untuk Meningkatkan Kemampuan Representasi Matematis dan Self Efficacy Siswa. UNIVERSITAS LAMPUNG. http://digilib.unila.ac.id/28584/2/TESIS TANPA BAB PEMBAHASAN.pdf

Erita, S. (2016). Beberapa Model, Pendekatan, Strategi, dan Metode dalam Pembelajaran Matematika. Tarbawi: Jurnal Ilmu Pendidikan, 1(2).

Festiyed, D. D. (2015). Modul Matakuliah Pengembangan Eveluasi dan Penilaian Proses Pembelajaran Fisika. Padang: Universitas Negeri Padang.

Gazali, R. Y. (2016). Pembelajaran matematika yang bermakna. Math Didactic: Jurnal Pendidikan Matematika, 2(3), 181-190.

Hadi, S. (2005). Pendidikan Realistik dan Implementasinya. Banjarmasin: Tulip.

Hidayati, K. (2013). Pembelajaran Matematika dengan pendekatan Pendidikan Matematika Realistik Indonesia (PMRI) di SD/MI. Cendekia: Jurnal Kependidikan Dan Kemasyarakatan, 11(1), 163181.

Hobri. (2009). Model-Model Pembelajaran Inovatif. Center for Society Studies.

Kamarullah, K. (2017). Pendidikan matematika di sekolah kita. Al Khawarizmi: Jurnal Pendidikan Dan Pembelajaran Matematika, 1(1), 21-32.

Kusumawati, N. (2017). Pengaruh Kemampuan Komunikasi dan Pemecahan Masalah Matematika terhadap Hasil Belajar Siswa dengan Pembelajaran Realistic Mathematic Education (RME). Delta: Jurnal Ilmiah Pendidikan Matematika, 1(1), 104-113. https://jurnal.unikal.ac.id/index.php/Delta/article/viewFile/467/429

Lestari, I. (2013). Pengembangan bahan ajar berbasis kompetensi. Padang: Akademia Permata, 1. 
Lismawati. (2010). Pengoptimalan Penggunaan Lembar Kerja Siswa. Rineka Cipta.

Marpaung, Y. (2001). Pendekatan realistik dan sani dalam pembelajaran matematika. Makalah Dalam Seminar Nasional "Pendidikan Matematika Realistik Indonesia” Tanggal, 14-15.

Ningsih, S. (2014). Realistic Mathematics Education: Model Alternatif Pembelajaran Matematika Sekolah. Jurnal Pendidikan Matematika, 1(2), 73-94. http://jurnal.uinantasari.ac.id/index.php/jpm/article/view/97

Nugraha, D. A., \& Binadja, A. (2013). Pengembangan bahan ajar reaksi redoks bervisi SETS, berorientasi konstruktivistik. Journal of Innovative Science Education, 2(1).

Prastowo, A. (2011). Panduan kreatif membuat bahan ajar inovatif. Yogyakarta: DIVA press.

Rusdi, M. (2018). Penelitian Desain dan Pengembangan Kependidikan. Depok: PT. RajaGrafindo Persada.

Silvianti, R., \& Bharata, H. (2016). Meningkatkan Kemampuan Komunikasi Matematis Siswa Melalui Pendekatan Realistic Mathematics Education (RME). https://publikasiilmiah.ums.ac.id/bitstream/handle/11617/7016/78_112_Makalah Rev_Rizka Silvianti Unila\%281\%29.pdf?sequence=1\&isAllowed=y

Sudibyo, B., \& Dr, P. (2007). Materi sosialisasi dan pelatihan kurikulum tingkat satuan pendidikan(KTSP). Jakarta: Departemen Pendidikan Nasional.

Suharta, I., \& Putu, G. (2001). Pembelajaran pecahan dalam matematika realistik. Makalah Disajikan Dalam Seminar Nasional Realistic Mathematics Education (RME), FMIPA UNESA, Surabaya, 24.

Treffers, A. (1991). Didactical background of a mathematics program for primary education. Realistic Mathematics Education in Primary School, 21-56.

Trianto, M. P. (2009). Mendesain model pembelajaran inovatif-progresif. Jakarta: Kencana.

Wijaya, A. (2012). Pendidikan matematika realistik suatu alternatif pendekatan pembelajaran matematika. Yogyakarta: Graha Ilmu.

Yezita, E. (2012). Mengkonstruksi Pengetahuan Siswa pada Materi Segitiga dan Segiempat Menggunakan Bahan Ajar Interaktif Matematika Berbasis Konstruktivisme. Jurnal Pendidikan Matematika, 1(1).

Zulkardi, Z. (1999). How to design mathematics lessons based on the realistic approach. 